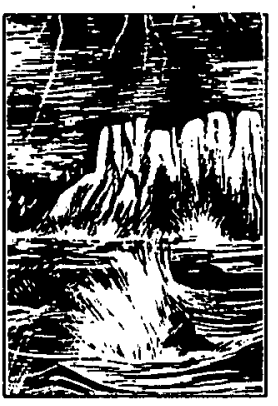

Announcing a new journal for 1994

\title{
Meteorological Applications
}

Published for the Royal Meteorological Society

Meteorological Applications is an exciting new journal devoted to publishing material describing the different applications of meteorology, with particular emphasis on developments within Europe.

In recent years there has been a lot of activity devoted to developing the quality and range of meteorological services provided to a wide range of customers. This has required meteorologists to become increasingly aware of the needs of the users of the information, and for users to have a greater understanding of the services.

Meteorological Applications aims to encourage this flow of information between providers and users.

\section{Features}

- Original articles

- Review articles

- News section

- Calendar of forthcoming conferences, colloquia and symposia

- Reports of important conferences

- Book reviews

- Correspondence

\section{Subscription}

Volume 1 in 1994: March, June, September and December: $\mathbf{6 9 6}$; Special arrangements exist for Royal Meteorological Society members; airmail f14 per year extra. ISSN 1350-4827

Further Information

Please send me a free sample copy of Meteorological Applications

$\checkmark \square$ Please send further information

I Name

Address

1

| Send to: Journal Marketing Dept,

Cambridge University Press, FREE-

POST*, The Edinburgh Building,

I Cambridge, CB2 IBR, UK

Tel: $+44(0) 223325806$

Fax: +44 (0)223 315052

"No postage noeded if posted within UK

In USA, Canada \& Mexico write to:

Cambridge University Press, 40 West

20th Street, New York, NY I00II-42Ir, USA

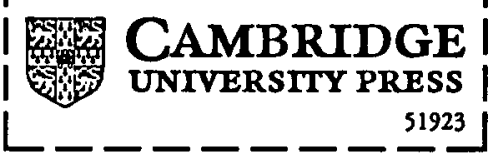




\title{
THE JOURNAL OF NAVIGATION
}

\author{
Volume 47 \\ 1994 \\ PUBLISHED UNDER THE AUTHORITY OF THE COUNCIL \\ EDITED BY J. F. KEMP
}

THE ROYAL INSTITUTE OF NAVIGATION AT THE ROYAL GEOGRAPHICAL SOCIETY I KENSINGTON GORE, LONDON SW 7 2AT 


\title{
THE ROYAL INSTITUTE OF NAVIGATION
}

\author{
PATRON
}

H.R.H. THE PRINCE PHILIP DUKE OF EDINBURGH, KG, $\mathrm{kT}$, oM

\section{OFFICERS AND COUNCIL 1993-94}

\author{
PRESIDENT \\ W. F. Blanchard \\ VICE PRESIDENTS \\ B. D'Oliveira, OBE \\ Wg Cdr J. Mitchell \\ TREASURER \\ H. J. Agnew \\ CHAIRMAN OF THE TECHNICAL COMMITTEE \\ D. M. Page \\ CHAIRMAN OF THE MEMBERSHIP \& FELLOWSHIP COMMITTEE \\ Captain A. N. Cockcroft \\ Other Members of Council \\ Dr J. D. Last \\ Dr C. Quereé \\ J. D. Reeve \\ Captain D. G. Ross \\ Captain R. A. Smith, RN \\ DIRECTOR \\ Group Captain D. W. Broughton, MBE, RAF
}

T. J. Bartlett

C. M. D. Beatty

Air Commodore N. Bonnor

Professor M. J. Dove

V. D. Hopkin 


\section{CONTENTS}

The Eva G. R. Taylor Lecture: Navigators and Mathematical Practitioners in Samuel Pepys's Day

H. WaLLIS

The ECDIS Paradox: A Controversial View on Navigation, Freedom and

Safety at Sea

F. BIANCHETTI

Mercator -425 Years Not Out

T. Hughes

The Air Traffic Capacity of Two-Dimensional Airspace

S. Ratcliffe

The Fisherman - Navigating to the Plaice

K. KNOX

Blinking Detection Methods for Loran-C

A. NiEUwLand

Design and Operation of a Computerized, On-Board, Weather Routeing System

R. H. Motte, R. Fazal, M. Epshteyn, S. Calvert and H. Wojdylak

TMSIM : A Runway Capacity Study for Frankfurt and Chicago O'Hare

Airports

D. Trivizas

The Nautical Almanac's Faulty Calculator Instructions 89

M. Pepperday

Visual Approach Guidance Indicator Systems $\quad 96$

J. R. C. Young

Position by Observation of a Single Body

R. Williams

On the Two-Body Running Fix

K. Grisson

Shortest Spheroidal Distance

T. Zukas

The Adventures of Leonard

J. B. Parker

An Interesting Problem in Spherical Trigonometry

O. Öztan, U. Özerman and Z. KiziLsu

Review

The Channel Navigation Information Service

A. H. Griffiths

Authenticity and Verification of Aeronautical Data K. ReID

The Russian Fleet's Navigational Aids in the Baltic Sea During the Eighteenth and Nineteenth Centuries VERA N. Afrossimova

Some Institutional Factors and Aspects Relating to a Civil Global Navigation Satellite System M. J. AsBury

Bus Identification, Communication and Control System (BICCS)

M. Frewer

Wide Area Differential GPS Field Study

1. Catchpole, P. Upton, A. Sinclair and J. Nagle

A Route Planning and Driver Information System for PLEIADES 159 M. Ness and M. Herbert

Integrated Navigation for Ocean Racing Boats T. THORNTON 
The Application of Advanced Systems - An Airline Perspective

K. REID

Monitoring the Integrity of GNSS

N. WARD

Towards a Global Navigation System

I 91

A. Stratton

Conflicts in Inshore Waters

208

P. S. Booth

Position Accuracy of Celestial Fixes

N. L. A. Bovens

The Use of a GPS-Equipped Aircraft as a Mobile Platform to Study the Propagation of Omega Navigation Signals

R. BArR, T. R. Armstrong and S. Arrell

Recent Technological Advances in the Control and Guidance of Ships N. A. J. Witt, R. Sutton and K. M. Miller

The Timing of Collision Avoidance Manoeuvres: Descriptive Mathematical Models

M. K. James

'A Note on the Use of GPS for the Identification of Marine Radar

Contacts'

E. V. Stansfield

The Author Replies

W. B. STAWELL

'The Royal Institute of What?' Tales of the Unexpected J. M. Sharpey-Schafer

Record

Air Navigation Systems Chapter 5. The Development of British Airborne Primary Radar, 1935-1945

B. KendaL

Assessment of the Potential Satellite Navigation Systems for Europe.

Results of a Study for the European Commission

H. Stich, W. F. Blanchard, W. Lechner, D. Kayser and H. Gaillard

Comparison of Two Multi-Site Reference Station Differential GPS Systems G. T. JOHNSTON

Use of GPS-Determined Attitude in Combination with Conventional Attitude Sensors

T. Mathisen And O. Orpen

The Impact of DGPS on Land, Marine and Air Navigation in Egypt H. EL-SaAdawY

Current Status of Flight Evaluation of DGPS-INS Hybrid Navigation System at NAL

H. Shingu, M. Murata, T. Ono and K. Ishikawa

DGPS Emergency Location System for Vehicles

D. VOGEL AND S. HARRER

The Development and Testing of Integrated Navigation Systems

M. A. Grenfell and J. A. Read

Drift Errors in Search and Rescue

M. Ross And R. Dawson

A Fast Satellite Selection Algorithm for Combined GPS and GLONASS

Receivers

E. MoK ANd P. Cross

Modelling Navigational Risk and Oil Spill Probabilities

A. K. S. QuON AND G. E. Bushell

The GNSS Transponder - A Cost-Effective Worldwide GNSS-Based Civil Aviation CNS/ATM, ATC, ATN Data Link and Collision Avoidance System Concept

J. Nilsson and H. Lans 
Small RCS Marine Surface Craft and their Radar Detection in Real

(Estuary) Sea Conditions

P. G. Adamopoulos

The D-Day Invasion of Europe, 1944

441

J. M. Sharpey-Schafer

'The ECDIS Paradox'

'The Nautical Almanac's Faulty Calculator Instructions'

A. D. MACFADYEN

J. M. Sharpey-Schafer

C. DE WIT

The Author Replies

447

M. Pepperday

Record

Review

$45^{\circ}$

$45^{1}$ 


\title{
THE ROYAL INSTITUTE OF NAVIGATION
}

\author{
Aims and Objects
}

The objects of the Institute are to unite in one body those who are concerned with or who are interested in navigation and to further its development. Navigation is conceived as applying to locomotion of all kinds and is perceived as encompassing aspects of : command and control, psychology and zoology, operational research, risk analysis, theoretical physics, operation in hostile environments, instrumentation, ergonomics, funancial planning and law as well as electronics, astronomy, mathematics, cartography and other subjects traditionally associated with navigation.

The aims of the Institute are to encourage the creation and dissemination of knowledge through research and development, to co-ordinate information from all the disciplines involved, to provide a forum in which new ideas and new products can have the benefit of informed and professional scrutiny and to further education and communication.

The Institute initiates conferences and symposia on specific subjects and has a programme of meetings at which lectures are given and discussed. There are standing Study Groups which keep under constant review pertinent aspects of navigation. The success of these Study Groups is crucially dependent on the active involvement of members.

The Institute publishes The Journal of Navigation three times a year. It contains papers which have been presented at meetings together with the ensuing discussion, other original papers, selected papers and reports from Study Groups, and book reviews. The Institute also publishes Navigation News six times a year which contains a full account of the Institute's proceedings and activities. This includes Branch News, a record of current navigational work, a diary of events, topical articles, news about Membership and advertising. A great deal of the Institute's work is international in character and is co-ordinated with that of similar organizations in other countries. There are also active Branches throughout the United Kingdom.

\section{Membership}

There are five classes of Membership of the Institute:

(I) Honorary members: Distinguished persons upon whom the Council may see fit to confer an honorary distinction.

(2) FELLows: Members, of at least three years' standing, holding certain qualifications laid down in the by-laws; these qualifications include having made a contribution of value to navigation.

(3) MEMmers: Persons over twenty-one years of age who satisfy the Council of their interest in navigation.

(4) STUDENT MEMBERs: Persons under twenty-five years of age studying at a recognized school or university with a view to making navigation, or an allied interest, their career.

(5) CORPORATE MEMBers: Organizations such as universities, navigation schools, government departments or companies, here and abroad, who are directly or indirectly interested in the science of navigation. Corporate Members are entitled to send representatives to all Institute meetings and to receive six copies of its publications. They are encouraged to take an active part in the Institute's work. Applications should be sent by letter addressed to the Director.

\section{Subscriptions}

Annual subscriptions to the Institute are payable in advance as follows:

Members and Fellows

$\$ 50.00$
$£ 10.00$
$\$ 350.00+V A T$

Student Members

The Institute's financial year begins on I July. Members in any category who are elected after I January in any year are only due for one half of their subscription until I July, when the full subscription for the next year becomes due. 


\section{THE JOURNAL OF}

\section{Navigation}

VOLUME 47 NUMBER 3 SEPTEMBER 1994

\section{O N T E N T S}

Air Navigation Systems Chapter 5. The Development of British Airborne Primary Radar, 1935-1945

B. Kendal

Assessment of the Potential of Satellite Navigation Systems for Europe. Results of a Study for the European Commission

H. Stich, W. F. Blanchard, W. Lechner, D. Kayser and H. Gaillard

Comparison of Two Multi-Site Reference Station Differential GPS Systems

G. T. Johnston

Use of GPS-Determined Attitude in Combination with Conventional Attitude

Sensors

T. Mathisen and O. Ørpen

The Impact of DGPS on Land, Marine and Air Navigation in Egypt

H. El-Saadawy

Current Status of Flight Evaluation of DGPS-INS Hybrid Navigation Systems at

NAL

H. Shingu, M. Murata, T. Ono and K. Ishikawa

DGPS Emergency Location System for Vehicles

D. Vogel and S. Harrer

The Development and Testing of Integrated Navigation Systems

M. A. Grenfell and J. A. Read

Drift Errors in Search and Rescue

M. Ross and R. Dawson

A Fast Satellite Selection Algorithm for Combined gPS and gLonass Receivers

E. Mok and P. Cross

Modelling Navigational Risk and Oil Spill Probabilities

A. K. S. Quon and G. E. Bushell

The GNSS Transponder-A Cost-Effective Worldwide GNSS-Based Civil Aviation CNS/ATM, ATC, ATN Data-Link and Collision Avoidance System Concept

J. Nilsson and H. Lans

Small rCs Marine Surface Craft and their Radar Detection in Real (Estuary) Sea

Conditions

P. G. Adamopoulos

The D-Day Invasion of Europe, 1944

J. M. Sharpey-Schafer

'The ECDIs Paradox'

J. N. Pasquay

'The Nautical Almanac's Faulty Calculator Instructions'

A. D. Macfadyen, J. M. Sharpey-Schafer and C. De Wit

The Author Replies

M. Pepperday

Record

Review 